\title{
Importance of childhood socioeconomic status on the current prevalence of Helicobacter pylori infection
}

\author{
H M Malaty, D Y Graham
}

\begin{abstract}
Helicobacter pylori infection is commoner in black and Hispanic people compared with age matched white people. $H$ pylori status was evaluated using an enzyme linked immunosorbent assay for anti-H pylori IgG in 150 healthy black and Hispanic people aged between 19 and 49 years. All were employed and had completed high school at least. Socioeconomic status during childhood was estimated from the parents' education and occupation(s) using a modified Hollingshead index and family income. Five social classes were defined (class $I$ =lowest, $\mathrm{V}=$ highest). The $H$ pylori prevalence was inversely related to the social class during childhood. It was $85 \%$ for class $I, 52 \%$ for combined classes II and III, and 11\% for classes IV and $V$ combined. The inverse correlation remained after adjustments were made for the present social class and age. $H$ pylori infection was also related to crowded living conditions (odds ratio 4.5: 95\% confidence interval $3 \cdot 3,5 \cdot 7$ ) for those who had had the most crowded living conditions during childhood). The increased prevalence of $H$ pylori in black and Hispanic people seems to be related to low socioeconomic status in childhood. These data are also consistent with the suggestion that childhood is a period of major risk for $H$ pylori infection.
\end{abstract}

(Gut 1994; 35: 742-745)

Helicobacter pylori infection is now accepted as the major cause of gastritis and has been aetiologically linked with duodenal ulcer disease, gastric ulcer disease, and gastric cancer. ${ }^{1-6}$ Once $H$ pylori infection is acquired, it seems that the duration of the infection is very long, possibly for life. The prevalence of $H$ pylori infection varies between races and ethnic groups, ${ }^{7-18}$ but it is not known if this difference is a result of different exposures (for example, cultural background, social and environmental factors) or genetic predisposition. ${ }^{7} 1920 \mathrm{H}$ pylori infection is twice as prevalent in black and Hispanic people than in age matched white people, even after adjusting for socioeconomic factors. ${ }^{14} \mathrm{We}$ suggested that this increase in prevalence reflected the fact that these groups have only recently moved out of a low socioeconomic class and the individuals carried with them the high rate of acquisition experienced in childhood. ${ }^{14}$
This study was designed to ask whether the socioeconomic background in childhood had a major influence on $H$ pylori prevalence in black and Hispanic adults.

\section{Methods}

STUDY POPULATION

The study population consisted of healthy Hispanic and black volunteers between the ages of 19 and 49 years who resided in the Houston metropolitan area. The main criteria for enrollment in the study was that the subject must have completed high school and be gainfully employed. Volunteers were recruited from the general population through local advertisements. We prescreened each volunteer to explain the study and to review the participants educational and occupational history. Each potential volunteer then completed a self administered screening questionnaire, the results of which were reviewed by a trained interviewer.

\section{QUESTIONNAIRE}

The questionnaire was designed to obtain demographic information such as the date and place of birth, race, gender, highest educational level, type of occupation, income, and information concerning childhood, such as parents' place of birth, education(s) and occupation, type of house and the community they lived in, number of rooms and number of people who lived in the house, and the family income during childhood. Enrollees were also asked if they, or any family members, had a history of peptic ulcer diseases. A history of peptic ulcer disease was an exclusion criteria.

The study was approved by the Institutional Review Board of Baylor College of Medicine. A consent form was signed by each volunteer before participation in the study.

\section{SEROLOGICAL METHODS}

A serum sample was obtained from each participant for evaluation of $\mathrm{IgG}$ antibody to the high molecular weight cell-associated proteins (HM-CAP, EPI, Westbury, NY) of p pylori. $^{21}$ The sera was stored at $-70^{\circ} \mathrm{C}$ until assay.

\section{METHODS OF ANALYSIS}

For the purpose of this study, we constructed composite indexes for socioeconomic class based on occupation, education (by applying 
TABLE I Educational and occupational categories used in forming the modified Hollingshead. Index of socioeconomic class

\begin{tabular}{llll}
\hline Class & Education & Occupation & Income \\
\hline I & Elementary education & Semi-skilled and unskilled workers & Low \\
II & High school & Skilled workers & Middle to low \\
III & High school & Clerks, sales, technician & Middle \\
IV & Some college & Minor professionals administrations & High to middle \\
V & $\begin{array}{l}\text { College graduate and } \\
\text { postgraduate }\end{array}$ & Major professionals & High \\
& & & \\
\hline
\end{tabular}

the Hollingshead index), ${ }^{22}$ and income. The composite index was used to measure the parents' socioeconomic class and the present socioeconomic class of the participants. Five occupational categories, four educational levels, and three income levels were used (Table I). A matrix of these factors was developed, from which we defined a social class scale ranging from one (I) to five (V). Parents with elementary education and unskilled occupation and low income were assigned to social class I. People with the high occupational levels and with graduate education and high income, such as lawyers or physicians, were assigned to social class $\mathrm{V}$. That matrix was used to determine the present and the childhood social class of the participants.

A crowding index was defined from dividing two factors; number of people living in the household by the number of rooms in the household. Three categories were identified A, B, and C: A had a crowding index less than 1 , B had an index between 1-2, and $C$ had an index more than 2 .

$H$ pylori infection was defined as a positive ELISA test result for the presence of anti$H$ pylori IgG.

\section{STATISTICAL ANALYSES}

The study population was categorised into three age groups, five childhood social classes, and four present social classes. The combination of five childhood social classes and four present social classes resulted in 20 social groups, with a small sample size in each group. We therefore combined the childhood social classes into three groups: I (lowest), II and III (intermediate), and IV and V (highest) and the present social classes into two groups II and III (intermediate), and IV and $\mathrm{V}$ (high) to provide sufficient numbers of individuals for a useful analysis. The MantelHaenszel $\chi^{2}$ test was used to examine the associations between $H$ pylori infection and the subject's characteristics. Logistic regression analysis was applied to assess any significant

TABLE II Prevalence rate of Helicobacter pylori IgG antibodies in relation to childhood and present social class

\begin{tabular}{|c|c|c|c|}
\hline Social class & $\begin{array}{l}\text { Total } \\
\text { population } \\
\text { No(\%) }\end{array}$ & $\begin{array}{l}\text { Blacks } \\
\text { No }(\%)\end{array}$ & $\begin{array}{l}\text { Hispanic } \\
\text { No }(\%)\end{array}$ \\
\hline \multicolumn{4}{|l|}{ Childhood social class: } \\
\hline Class I & $34(85)$ & $13(85)$ & $21(86)$ \\
\hline Classes II and III & $97(52)$ & $44(61)$ & $53(43)$ \\
\hline Classes IV and V & 19 (11) & $3(33)$ & $16(6)$ \\
\hline \multicolumn{4}{|l|}{ Present social class: } \\
\hline Classes II and III & $106(60)$ & $53(66)$ & $53(55)$ \\
\hline Classes IV and V & 44 (39) & $7(57)$ & $37(35)$ \\
\hline
\end{tabular}

$\star$ Percentage of $H$ pylori positive. association of the study variables on the frequency of $H$ pylori infection. Odds ratios and confidence intervals were measured based on maximum likelihood estimates of regression parameters. The data were analysed using the SAS program (SAS Institute, Cary, $\mathrm{NC}$ ).

\section{Results}

A total of 150 subjects (60 black and 90 Hispanic) were studied. The overall prevalence rate of $H$ pylori infection for the total population was $(54 \%)-65 \%$ for black and $47 \%$ for Hispanic people. The difference in prevalence between black and Hispanic people was not significant after controlling for childhood social class and present social class $(p=0 \cdot 24)$. Table II shows the distribution of the prevalence rates of $H$ pylori antibody in relation to childhood social class and the present social class for the total population and for blacks and Hispanics separately.

The prevalence of $H$ pylori infection was examined in relation to childhood social class. It was highest in the lowest social class (I) $(85 \%)$, intermediate in the middle class (II and III) $(52 \%)$, and lowest in the highest class (IV and V) $(11 \%)$. The difference was highly significant $(p=0 \cdot 0001)$. The inverse correlation pattern between the $H$ pylori rate and childhood social class was observed in the total population and in black and Hispanic people separately. The inverse relationship remained when the present social class was examined in relation to the prevalence of $H$ pylori infection.

Because of the known effect of age on the prevalence of $H$ pylori infection, we examined the age-specific prevalence rates by childhood social class and present social class (Table III). There were no statistically significant differences in $H$ pylori prevalence between the three age groups. However, we observed statistically significant differences between the $H$ pylori prevalence and childhood social class within each age specific group. When the distribution of age-specific $H$ pylori infection in relation to the present social class was examined, a different pattern was observed. The prevalence rate of $H$ pylori infection was highest in the oldest age group (40-49 years) for both social groups and there were no significant differences for $H$ pylori rates within each age group (Table III).

When we examined the effect of the present and childhood social class on the prevalence of $H$ pylori, we found that those with the lowest childhood social class had the highest rates of infection regardless to their present social class (Figure).

\section{RISK OF H PYLORI INFECTION AND} SOCIOECONOMIC CLASSES

Table IV presents the results of stepwise logistic regression analysis with $H$ pylori as the dependant variable. The youngest age group (19 to 29 years) showed the lowest rate of the infection (42\%). That difference was not significant when childhood social class and 
TABLE III Age-specific prevalence rates by childhood and present social class

\begin{tabular}{|c|c|c|c|c|c|}
\hline $\begin{array}{l}\text { Social class/ } \\
\text { age group }(y)\end{array}$ & $\begin{array}{l}\text { Class I } \\
\text { No }(\%)^{\star}\end{array}$ & $\begin{array}{l}\text { Classes } \\
\text { II and III } \\
\text { No }(\%)\end{array}$ & $\begin{array}{l}\text { Classes } \\
I V \text { and } V \\
\text { No }(\%)\end{array}$ & $p$ Value $\dagger$ & $\begin{array}{l}\text { Total } \\
\text { No }(\%,\end{array}$ \\
\hline \multicolumn{6}{|c|}{ Childhood social class: } \\
\hline $19-29$ & $6(83)$ & $45(49)$ & $14(0)$ & 0.0001 & $65(42)$ \\
\hline $30-39$ & $14(93)$ & $33(58)$ & $5(40)$ & 0.003 & $52(65)$ \\
\hline $40-49$ & $14(79)$ & $19(47)$ & 0 & - & $33(61)$ \\
\hline \multicolumn{6}{|c|}{ Present social class: } \\
\hline $19-29$ & 0 & $39(49)$ & $26(31)$ & $0 \cdot 150$ & $65(42)$ \\
\hline $30-39$ & 0 & $42(28)$ & $10(40)$ & $0 \cdot 060$ & $52(65)$ \\
\hline $40-49$ & 0 & $25(60)$ & $8(63)$ & 0.900 & $33(61)$ \\
\hline
\end{tabular}

^Percentage of $H$ pylori positive.

tp Value represents the statistical difference between social classes within each age specific group. present social class were entered into the model. There was a strong inverse correlation between childhood social class and $H$ pylori infection. The odds ratio for people from a low childhood social class was $54 \cdot 6$, and this value was 8.9 for those from middle social class. Because of the significant associations between childhood social class and present social class and crowding index $(\mathrm{p}>0.05)$, all the study variables were fitted into the logistic regression model to prevent any confounding effect. The results did not alter the observed strong effect of childhood social class as a risk of acquiring the infection.

After controlling for age, the odds ratio for crowded living conditions was 4.5 (95\% CI $3.3,5.7)$ for those who had the greatest crowded conditions during childhood. Growing up in rural areas was also associated with a higher risk of acquiring the infection $(\mathrm{OR}=3 \cdot 1,95 \% \mathrm{CI} 2 \cdot 2,4)$. There was a significant correlation between growing up in a rural area and social class during childhood. Being born outside the USA had no significant effect on $H$ pylori prevalence in these relative high prevalence groups.

\section{Discussion}

In this population based generational cohort study we asked why black and Hispanic people seem to have a higher acquisition rate of $H$ pylori infection than white people. We were able to identify risk factors associated with the acquisition of $H$ pylori infection. We found

TABLE IV The results of logistic regression analysis of the study parameters and their association with Helicobacter pylori infection

\begin{tabular}{|c|c|c|c|c|}
\hline Factor & Total (\%) & $\begin{array}{l}\text { Odds } \\
\text { ratio }\end{array}$ & $\begin{array}{l}95 \% \text { Confidence } \\
\text { interval }\end{array}$ & p Value \\
\hline \multicolumn{5}{|l|}{ Age $(y)$ : } \\
\hline $19-29$ & $65(42)$ & - & & \\
\hline $30-39$ & $52(65)$ & 1.9 & $1 \cdot 1,2 \cdot 7$ & $0 \cdot 127$ \\
\hline $40-49$ & $33(61)$ & $1 \cdot 1$ & $0 \cdot 1,2 \cdot 1$ & 0.979 \\
\hline \multicolumn{5}{|l|}{ Childhood social class: } \\
\hline IV and V & $19(11)$ & - & & \\
\hline II and III & $97(52)$ & $8 \cdot 9$ & $7 \cdot 3,10 \cdot 5$ & 0.005 \\
\hline I & $43(85)$ & $54 \cdot 6$ & $52 \cdot 7,56 \cdot 5$ & 0.001 \\
\hline \multicolumn{5}{|l|}{ Present social class: } \\
\hline IV and V & $44(39)$ & - & & \\
\hline II and III & $106(60)$ & $2 \cdot 2$ & $1 \cdot 5,2 \cdot 9$ & $0 \cdot 030$ \\
\hline \multicolumn{5}{|l|}{ Born in USA: } \\
\hline Yes & $127(55)$ & - & & \\
\hline No & $23(48)$ & $1 \cdot 2$ & $0 \cdot 8,2 \cdot 2$ & 0.646 \\
\hline \multicolumn{5}{|l|}{ Type of community: } \\
\hline Urban and suburban & $118(49)$ & & & \\
\hline Rural & $32(72)$ & $3 \cdot 1$ & $2 \cdot 2,4 \cdot 0$ & 0.010 \\
\hline \multicolumn{5}{|l|}{ Crowding index: } \\
\hline Low & $24(29)$ & - & & \\
\hline Middle & $94(56)$ & $3 \cdot 1$ & $2 \cdot 1,4 \cdot 1$ & 0.002 \\
\hline High & $32(66)$ & $4 \cdot 5$ & $3 \cdot 3,5 \cdot 7$ & 0.014 \\
\hline
\end{tabular}

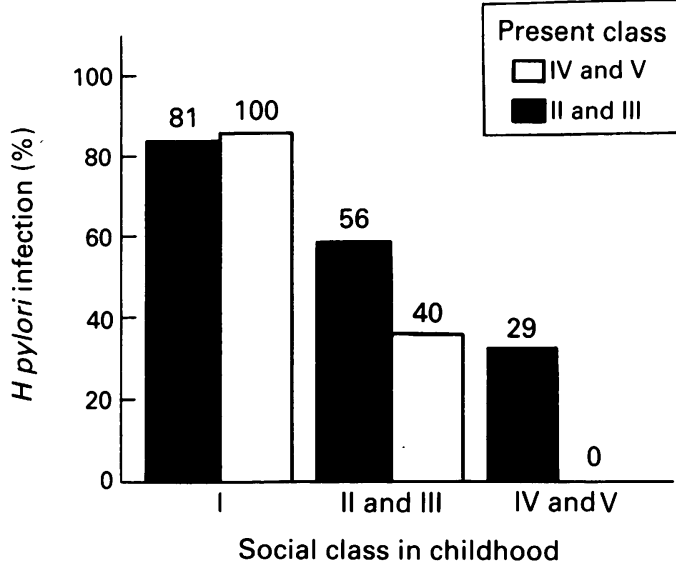

Relation between the prevalence of Helicobacter pylori infection and socioeconomic class in childhood and present socioeconomic class (social class $1=$ lowest; $5=$ highest)

a strong inverse relationship between the prevalence rate of $H$ pylori infection and childhood socioeconomic class, which persisted after controlling for confounding variables. A high prevalence rate of $H$ pylori infection was observed in those who had low socioeconomic standards during their childhood, regardless of their present social class (Figure). The interaction between childhood and present socioeconomic status may largely explain the variation in the prevalence rates in different ethnic groups.

In several previous studies, age has been found to be an important risk factor for acquisition of $H$ pylori infection. A recent cohort study divided individuals into three classes (1969-74, 1975-81, 1982-87) and found that the age adjusted prevalence rate of $H$ pylori infection was higher in the early 1970 s than recently. ${ }^{23}$ It was suggested this was due to an age related risk based on a cohort effect and improvements in socioeconomic standards, living conditions, and hygiene. Alternatively, and based on our results, the populations of older age groups may have differed from younger age groups in their backgrounds and their childhood socioeconomic class. Our data suggest that low socioeconomic class and high density of living, regardless of the place of birth enhance the acquisition of $H$ pylori infection.

The prevalence of $H$ pylori infection in children has varied in different areas. ${ }^{124-35}$ For example, in Saudi Arabia ${ }^{25} 40 \%$ of children between 5 and 10 years of age and in India ${ }^{33}$ $60 \%$ of children aged $3-10$ years were infected with $H$ pylori. In the USA one study found that $10 \%$ to $15 \%$ of children in the 3-5 year age group were infected. ${ }^{24}$ Other studies from developed countries have reported $H$ pylori infection to be much less common in that age group. ${ }^{14} 15$ The variation in the prevalence rates of $H$ pylori within and among populations of children suggests that factors within the population influence the rate of acquisition or transmission of the organism. One such association may be crowded living conditions. The association we found between crowded living conditions during childhood and $H$ pylor infection is also consistent with the findings of 
several previous studies. ${ }^{26} 3435$ The higher prevalence of $H$ pylori infection in children with $H$ pylori infected asymptomatic parents compared with those with $H$ pylori negative index parents supports the concept that close contact has a role in transmission. ${ }^{19}$

Because of the significant correlation between low socioeconomic level and crowded living conditions during childhood, future investigations of the epidemiology of $H$ pylori in children should evaluate the role of kindergartens or day care centres in $H$ pylori transmission. Such studies may help determine whether children have a role the transmission of $H$ pylori infection or whether they are mere victims who acquired $H$ pylori infection from the environment. This will provide a direction for investigation of adverse childhood socioeconomic status and environmental factors which could be modified.

This work was supported by the Department of Veterans' Affairs and by the generous support of Hilda Schwartz. The investigators also acknowledge the help of Valeria Tapscott, Charles Hachem, and Dr Mohammad Al-Assi.

1 Graham DY, Klein PD, Evans DG, Fiedorek SC, Evans DJ $\mathrm{Jr}$, Adam E, Malaty HM. Helicobacter pylori: epidemiology, relationship to gastric cancer and the role of infants in transmission. Eur 7 Gastroenterol Hepatol 1992; 4 (suppl 1): S1-S6.

2 Megraud F, Lamouliatte $\mathrm{H}$. Helicobacter pylori and duodenal ulcer. Evidence suggesting causation. Dig Dis $S c i$ nal ulcer. Evidence

3 Correa $P$. Is gastric carcinoma an infectious disease? $N$ Engl f Med 1991; 325: $1170-1$.

4 Taylor DN, Blaser MJ. The epidemiology of Helicobacter pylori infection. Epidemiol Rev 1991; 13: 42-59.

5 Graham DY. Helicobacter pylori: its epidemiology and its role in duodenal ulcer disease. $\mathcal{F}$ Gastroenterol Hepatol 1991; 6: 105-13

6 Graham DY, Adam E, Klein PD, Evans DJ Jr, Evans DG, Hazell SL, et al. Epidemiology of Campylobacter pylori infection. Gastroenterol Clin Biol 1989; 13: 84-8B

7 Graham DY, Malaty HM, Evans DG, Evans DJ Jr, Klein PD, Adam E. Epidemiology of Helicobacter pylori in an asymptomatic population in the United States. Effect of age, race, and socioeconomic status. Gastroenterology age, race, and socio.

8 Morris A, Nicholson G, Lloyd G, Haines D, Rogers A, Taylor D. Seroepidemiology of Campylobacter pyloridis. NZ Med $\mathscr{f}$ 1986; 99: 657-9.

9 Webberley MJ, Webberley JM, Newell DG, Lowe P, Melikian V. Seroepidemiology of Helicobacter pylori infection in vegans and meat-eaters. Epidemiol Infect 1992; 108: 457-62.

10 Graham DY, Klein PD, Opekun AR, Boutton TW, Evans DJ Jr, Evans DG, et al. Epidemiology of Campylobacter
pylori infection: ethnic considerations. Scand $\mathcal{F}$ Gastroenterol 1988; 142 (suppl): 9-13.

11 Dwyer B, Kaldor J, Tee W, Marakowski E, Raios K. Antibody response to Campylobacter pylori in diverse ethnic groups. Scand $\mathcal{F}$ Infect Dis 1988; 20: 349-50.

12 Dwyer B, Sun NX, Kaldor J, Tee W, Lambert J, Luppino M, Flannery G. Antibody response to Campylobacter M, Flannery $G$. Antibody response to Campylobacter pylori in an ethnic group lackin
f Infect Dis 1988; 20: 63-8.

13 Dooley CP, Cohen H, Fitzgibbons PL, Bauer M, Appleman MD, Perez-Perez GI, Blaser MJ. Prevalence of Helicobacter pylori infection and histologic gastritis in asymptomatic persons. N Engl F Med 1989; 321: 1562-6.
14 Malaty HM, Evans DG, Evans DJ Jr, Graham DY. Helicobacter pylori in Hispanics: comparison with blacks and whites of similar age and socioeconomic class. Gastroenterology 1992; 103: 813-6.

15 Dehesa M, Dooley CP, Cohen H, Fitzgibbons PL, PerezPerez GI, Blaser MJ. High prevalence of Helicobacter pylori infection and histologic gastritis in asymptomatic Hispanics. $\mathcal{F}$ Clin Microbiol 1991; 29: 1128-31.

16 Smoot DT, Scott VF. The role of Helicobacter pylori in the pathogenesis of acid-peptic disease. Foumal Associated Academic Minority Physician 1992; 3: 46-9.

17 Schubert TT, Schnell GA. Prevalence of Campylobacter pylori in patients undergoing upper endoscopy. pylori in patients undergoing

18 Hopkins RJ, Russell RG, O'Donnoghue JM, Wasserman SS, Lefkowitz A, Morris JG Jr. Seroprevalence of Helicobacter pylori in Seventh-Day Adventists and other Helicobacter pylori in Seventh-Day Adventists and other
groups in Maryland. Lack of association with diet. groups in Maryland. Lack of a

19 Malaty HM, Graham DY, Klein PD, Evans DG, Adam E, Evans DJ. Transmission of Helicobacter pylori infection. Studies in families of healthy individuals. Scand $\dot{f}$ Gastroenterol 1991; 26: 927-32.

20 Malaty HM, Engstrand L, Pederson N, Graham DY. Is there a genetic influence in Helicobacter pylori susceptibility and transmission: the twin study [Abstract]. Am $\mathcal{F}$ Gastroenterol 1992; 399: 1342.

21 Evans DJ Jr, Evans DG, Graham DY, Klein PD. A sensitive and specific serologic test for detection of Campylobacter pylori infection. Gastroenterology 1989; 96: 1004-8.

22 Hollingshead AB. Two Factor index of social position. New Haven, CT: Yale University Press, 1957.

23 Parsonnet J, Blaser MJ, Perez-Perez GI, Hargrett-Bean N, Tauxe RV. Symptoms and risk factors of Helicobacter pylori infection in a cohort of epidemiologists. Gastroenterology 1992; 102: 41-6.

24 Fiedorek SC, Malaty HM, Evans DG, Pumphrey CL, Casteel HB, Evans DJ Jr, et al. Factors influencing the epidemiology of Helicobacter pylori infection in children. Pediatrics 1991; 88: 578-82.

25 al Moagel MA, Evans DG, Abdulghani ME, Adam E, Evans DJ, Jr, Malaty HM, et al. Prevalence of Helicobacter (formerly Campylobacter) pylori infection in Saudia Arabia, and comparison of those with and without uppror upper gastrointestir

26 Mitchell HM, Li YY, Hu PJ, Liu O, Chen M, Du GG, et al. Epidemiology of Helicobacter pylori in southern China: Epidemiology of Helicobacter pylori in southern China:
identification of early childhood as the critical period for identification of early childhood as the critical

27 Blecker U, Vandenplas Y. Helicobacter pylori seropositivity in symptom-free children [Letter]. Lancet 1992; 339: 1537.

28 Asaka $M$, Kimura $T$, Kudo $M$, Takeda $H$, Mitani S, Miyazaki T, et al. Relationship of Helicobacter pylori to serum pepsinogens in an asymptomatic Japanese population. Gastroenterology 1992; 102: 760-6.

29 Hardikar W, Davidson PM, Cameron DJ, Gilbert GL, Campbell PE, Smith AL. Helicobacter pylori infection in children. $\mathcal{F}$ Gastroenterol Hepatol 1991; 6: 450-4.

30 Perez-Perez GI, Dworkin BM, Chodos JE, Blaser MJ. Campylobacter pylori antibodies in humans. Ann Intern Med 1988; 109: 11-7.

31 Mitchell HM, Lee A, Berkowicz J, Borody T. The use of serology to diagnose active Campylobacter pylori infection. Med f Aust 1988; 14

32 Graham DY, Adam E, Reddy GT, Agarwal JP, Agarwal R, Evans DJ Jr, et al. Seroepidemiology of Helicobacter pylori infection in India. Comparison of developing and developed countries. Dig Dis Sci 1991; 36: 1084-8.

33 Klein PD, Graham DY, Gaillour A, Opekun AR, Smith EO. Water source as risk factor for Helicobacter pylori infection in Peruvian children. Gastrointestinal Physiology Working Group. Lancet 1991; 337: 1503-6.

34 Mendall MA, Goggin PM, Molineaux N, Levy J, Toosy T, Strachan $\mathrm{D}$, et al. Childhood living conditions and Helicobacter pylori seropositivity in adult life. Lancet 1992; 339: 896-7.

35 Baker DJP, Coggon D, Osmond C, Wickham C. Poor housing in childhood and high rates of stomach cancer. Br $\mathcal{F}$ Cancer 1990; 61: 575-8. 